\title{
The Influence of Gratitude on Body Image Among Male Adolescents
}

\author{
Afifah Chusna Az Zahra", ${ }^{*}$ Pravissi Shanti ${ }^{1}$, and Fonny Dameaty Hutagalung ${ }^{2}$ \\ ${ }^{1}$ Universitas Negeri Malang, Malang, Indonesia \\ ${ }^{2}$ Malaya University, Kuala Lumpur, Malaysia \\ ORCID \\ Afifah Chusna Az Zahra; https://orcid.org/0000-0002-1162-6530
}

Abstract. Adolescence is one of the important periods in human life. During this period, adolescents experience various changes, including physical changes. These physical changes can have an impact on the adolescent's perspective of the body, known as body image. Body image is related to gratitude. This study aimed to examine the impact of gratitude on body image in male adolescents. A correlational quantitative research method was used. The study sample consisted of 314 males aged 12-21 years old who were living in Malang City. The research instruments consisted of a gratitude scale and a body image scale made by the researchers. Data validity was examined

Corresponding Author: Afifah Chusna Az Zahra; email: afifahchusna1@gmail.com

Dates

Published 28 January 2022

Publishing services provided by Knowledge

(c) Afifah Chusna Az Zahra et

al.. This article is distributed

under the terms of the

which permits unrestricted use and redistribution provided that the original author and source are credited.

Selection and Peer-review under the responsibility of the ICoPsy Conference Committee.

\section{G OPEN ACCESS} by three psychologists and item difference tests. Data reliability was calculated using Cronbach's Alpha formula with a coefficient of 0.9. Data were analyzed using simple linear regression analysis. The results showed that gratitude had a significantly positive influence on body image. Male adolescents should be supported to understand the importance of gratitude so as to minimize the occurrence of negative body image.

Keywords: gratitude, body image, male adolescents

\section{Introduction}

Adolescence is a phase in human development. Adolescence is a transition period in the span of human life that connects childhood with adulthood characterized by physical, cognitive, and socioemotional development [1]. According to Ramanda et al. [2], adolescence is when individuals begin to look for their true identity by finding out, trying, failing, and finally finding what suits them. At this time, adolescents experience turmoil due to physical changes, which will affect the development of thinking, language, emotion, and social skills. Some developmental experts differ regarding the age range of adolescence. Santrock [1] stated that adolescence begins from the age of 10 to 22 years old. Meanwhile, according to Papalia and Olds, adolescence starts at 12 or 13 years old and ends in the teens or early twenties [3]. In his book, Monks et al.[4] discuss the age range of adolescence, which takes place between the ages of 12 to 21 .

During this phase, adolescents experience changes, one of which is rapid physical changes accompanied by sexual maturity. These changes make teenagers feel unsure 
of themselves and their abilities. Rapid physical changes, both internal changes such as the circulatory, digestive, and respiratory systems, and external changes, namely height, weight, and body proportions, significantly affect adolescents' development and self-concept [3]. In addition to that, there is the need to fulfill the beauty standard shaped by society. This may psychologically affect adolescents. Excessive attention to the physical appearance (body shape, etc.) usually occurs during puberty, namely in early adolescence [1]. Teenagers generally develop a personal perception or image of their physical appearance following body image or known as body image. Grimm \& Schwartz [5] describes body image as an individual's thoughts, feelings, attitudes, and perceptions about his or her own body. Based on Denich \& Ifdil [6], body image is a picture of a person's perception of an ideal body and how they want their body to look like based on societal norms. Body image can develop through interactions with other people and the social environment [7].

Adolescents who possess a positive body image will have a positive judgment and view of their body size and shape and feel comfortable with their body condition, manifested in a confident attitude and positive self-concept [7]. The form of a positive body image is to respect his body and feel proud and confident with his current body condition. A positive body image is essential for teenagers because when a teenager has a negative body image, it will impact various psychological aspects of him, such as negatively viewing his current body condition such as body shape and size. In addition, they also feel inferior and worried about their bodies, which results in dissatisfaction. Such a negative body image makes it difficult for teenagers to accept themselves, thus leading to the inability to take in criticism from others, not responding to praise, and being pessimistic. Body image issues are not only experienced by teenage girls but also teenage boys, or male adolescents. The issue is more directed at body proportions, weight, body shape, and height in teenage boys.

Researchers have conducted an initial survey on 75 male adolescents in Malang City on January 5, 2021. Based on the survey, it was found that $61.3 \%$ experienced body image problems, while $38.7 \%$ did not experience these problems. Body image problems are related to weight, body shape, height, skin color, facial and hair problems, and feeling less attractive. The most influential factors on these problems are selfperception (45.3\%), interpersonal relationships (22.7\%), environment (17.3\%), and past trauma (8\%). The most influential social media on body image problems are Instagram (78.7\%), TikTok (6.7\%), YouTube (5.3\%), and Facebook (5.3\%). Their efforts to foster a positive body image are by taking care of the body, exercising, eating nutritious foods, adopting a healthy lifestyle, maintaining the appearance, and setting the mind 
to be positive. From the survey results, it can be assumed that many male teenagers in Malang experience body image problems.

The development of body image is motivated by several factors, one of which is social media. Coen et al. [8] and Barron et al. [9] prove that there is a relationship between media exposure and individual physical appearance dissatisfaction. In addition to the influence of media exposure, other factors that affect body image, Nurvita \& Handayani [10] confirmed that cultural socialization, interpersonal experience, physical characteristics, and personality factors played a huge role in body image. In the personality factor, gratitude plays a significant role in the development of body image in adolescents. Layous et al. [11] define gratitude as a general tendency to appreciate the good things in their lives. Similarly, gratitude is expressed as a positive emotion in the way people assert happiness and gratitude for the kindness received (Seligman in Prabowo [12] ). Thus, it is established that gratitude is a condition in which a person is aware of and grateful for the good things in his/her life.

Gratitude can generate positive emotions that impact the way individuals evaluate themselves, including their body image. A male adolescent expresses gratitude for his body by accepting who he is, feeling satisfied with his body, not comparing his physical appearance with others, and appreciating his body. Adolescents with extreme gratitude will accept their physical appearance and appear more confident. Meanwhile, adolescents with a lack of gratitude tend to feel inferior to others because they are less grateful for what they have. Feelings of dislike and lack of love for one's body will encourage people to change the way they appear. Many people are not grateful for their appearance and body image; hence they make various efforts to improve their appearance. In addition, a low sense of gratitude can also lead to psychological problems such as anxiety, eating disorders, and even depression. Research related to gratitude conducted by Dwinanda [13] and Widawati et al. [14] resulted in a positive and significant relationship between gratitude and body image in adolescents.

Based on previous studies, the researcher is interested in examining the role of gratitude on body image in adolescent males.among male adolescents. This study aims to examine the role of gratitude on body image in male adolescents in Malang. Malang City was chosen as the research location because Malang is a big city, and many students pursue their studies in Malang. Since Malang is considered a big city, this may affect the mindset and perception of teenage boys, especially in terms of body image. This research is relatively new because the previous research primarily focused on female adolescents, and there is little to no discussion on body image in male adolescents. 


\section{Literature Review}

\subsection{Gratitude}

Gratitude is described as a willingness to acknowledge an increase in value that is not acquired in one's experience and has been discussed and conceptualized as an emotion, attitude, moral virtue, habit, personality trait, or coping response [15]. Jansbeken et al. [16] mentioned that gratitude is conceptualized as a state and an attribute. This Gratitude comes from a state that depends on attribution or affective-cognitive based on the ability to empathize, which stems from how a person evaluates the benefits received as a positive result and recognizes that this positive outcome comes from external sources. Emmon and McCullough (in Robustelli \& Whisman[17]) further defines gratitude as a person's perception of himself that is positive, not always worthy or acceptable, caused by the actions of others.

There are three aspects of gratitude according to Watkins et al., [18] as follows:

\subsubsection{Sense of abundance}

Individuals with gratitude always have a sense of abundance and pleasure, both in accepting situations and in bad things, they do not feel deprived though. Individuals feel that they are treated well by others and respect themselves. In addition, someone who is grateful does not feel that life is bad and thinks he has been treated fairly because everyone has benefits for himself and for others.

\subsubsection{Simple appreciation}

A grateful person is characterized by a tendency to appreciate every joy that has been obtained, even though it is small or simple that is currently available. By feeling grateful, a person will get his own satisfaction and tend to be happy in his life. Individuals who appreciate pleasure in a simple and not excessive way tend to experience gratitude behavior.

\subsubsection{Social appreciation}

A grateful person realizes the importance of appreciating every contribution made by others so that it becomes an impetus to create positive emotions. The individual also 
recognizes the importance of expressing appreciation or help that has been given by others. The attitude of accepting and giving appreciation to oneself and others that can make a positive influence on welfare for himself.

\subsection{Body Image}

Body image is interpreted as various constructions consisting of affective, cognitive, perceptual, and behavioral components [19]. Pursuant to Cash \& Pruzinky (in Ahadzadeh et al.,[20]), body image refers to a person's cognitive and emotional evaluation of their body size and shape and the extent to which they place their physical appearance. The affective dimension of body image is a person's emotions about his appearance and measures feelings related to weight problems and others. Cognitive dimensions of body image are beliefs, thoughts, and attributions related to appearance. Based on research by Clay, Viglones \& Dittmar (in Turel et al.,[21]), irregular eating patterns are often associated with socio-cultural pressures and body image problems. Likewise, Grimm \& Schwartz [5] depicted body image as an individual's thoughts, feelings, attitudes, and perceptions about his or her own body.

The aspects of body image according to Cash \& Pruzinsky [22] as follows:

\subsubsection{Appearance evaluation}

This aspect relates to an evaluation of the level of satisfaction with one's body and overall physical appearance obtained from self-evaluation or other people's reactions.

\subsubsection{Appearance orientation}

This aspect relates to the individual's attention to his appearance and there are efforts made to improve and enhance his appearance.

\subsubsection{Overweight preoccupation}

This aspect measures the level of anxiety about obesity, individual awareness of weight, and the tendency to go on a diet to lose weight and limit eating patterns. 


\subsubsection{Self classified weight}

The self-classified weight aspect relates to the individual's perception of the ideal body and the assessment of body weight ranging from very thin to very fat.

\section{Method}

This research was designed using a quantitative correlational approach. Quantitative research can be interpreted as a research method based on the philosophy of positivism [23] . Quantitative research is used to examine certain populations or samples, data collection using research instruments, data analysis is quantitative/statistical, with the aim of testing predetermined hypotheses. Participants in this study amounted to 314 people with the criteria for being teenagers, namely age of 12-21 years old, male gender, and living in Malang City. Data collection techniques using a scale that is distributed online via a Google form. The data collection tool uses two psychological scales compiled by the researcher, including the gratitude scale based on the aspects of gratitude put forward by the researcher Watkins et al.[18] and the body image scale based on body image aspects proposed by [22] . The instrument validity test used a content validity test and different tests. Validity tests used in this study include content validity and item difference tests.

Content validity on the gratitude scale using the Aiken's $V$ formula shows that all items from the body image scale have a coefficient of $V \geq 0.05$, with the $V$ index moving between 0.333-0.417. The valid gratitude scale items are 36 items. The item test was carried out on 55 male adolescents in Malang City. The result was that 30 items were used with different item indexes moving from 0.371 to 0.741 . Reliability test with Alpha Cronbach resulted in a gratitude scale of 0.939 , classified as very high. Content validity on the body image scale using the Aiken's $V$ formula illustrates that all items from the body image scale have a coefficient of $V \geq 0.05$, with the $V$ index moving between 0.583-0.667. The item test was carried out on 55 male adolescents in Malang City. The result was that 32 items were used with different item indexes moving from 0.296 to 0.743 . A reliability test with Alpha Cronbach was also conducted and it resulted in a body image scale of 0.904 , which is relatively high. The data analysis technique used simple linear regression analysis. 
TABLE 1: Respondents' demographic data.

\begin{tabular}{|c|c|c|c|}
\hline \multirow[t]{11}{*}{ Age } & Age Group & Frequency & Percentage (\%) \\
\hline & 12 years old & 1 & 0,318 \\
\hline & 13 years old & 1 & 0,318 \\
\hline & 14 years old & 1 & 0,318 \\
\hline & 15 years old & 4 & 1,272 \\
\hline & 16 years old & 6 & 1,908 \\
\hline & 17 years old & 4 & 1,272 \\
\hline & 18 years old & 25 & 7,950 \\
\hline & 19 years old & 45 & 14,310 \\
\hline & 20 years old & 76 & 24,168 \\
\hline & 21 years old & 151 & 48,089 \\
\hline \multirow[t]{4}{*}{ Last Education } & Primary School & 2 & 0,637 \\
\hline & Junior High School & 7 & 2,229 \\
\hline & Senior High School & 186 & 59,236 \\
\hline & University & 119 & 37,898 \\
\hline \multirow{5}{*}{$\begin{array}{l}\text { Domicile } \\
\text { Region }\end{array}$} & Blimbing District & 43 & 13,694 \\
\hline & Klojen District & 52 & 16,560 \\
\hline & Lowokwaru District & 130 & 41,401 \\
\hline & Sukun District & 64 & 20,382 \\
\hline & Kedungkandang District & 25 & 7,96 \\
\hline \multirow[t]{5}{*}{ Work } & College & 283 & 90,127 \\
\hline & Student & 23 & 7,325 \\
\hline & Entrepreneur & 3 & 0,955 \\
\hline & Private Sector Employee & 4 & 1,274 \\
\hline & Civil Servants & 1 & 0,318 \\
\hline
\end{tabular}

\section{Result and Discussion}

\subsection{Result}

\subsubsection{Descriptive analysis results}

\subsubsection{Illustration of body image and gratitude}

The statistics analysis result displays an average score of $M=103,97(S D=13,922)$ for the gratitude scale and an average body image score of $M=92,31$ ( $S D=14,219$ ). As for a descriptive illustration of both scales (gratitude and body image), the details are presented below in Tables 2 and 3.

The categorization in table 2 discloses that 30 male adolescents in Malang possess a high level of gratitude with a percentage of $9,6 \%$. There are 234 respondents with 
TABLE 2: Gratitude data categorization.

\begin{tabular}{l|ll}
\multicolumn{2}{c}{ Gratitude } \\
Category & Number of Participants & Percentage (\%) \\
Low & 50 & 15,9 \\
Medium & 234 & 74,5 \\
High & 30 & 9,6
\end{tabular}

TABLE 3: Body image data categorization.

\begin{tabular}{lll} 
Category & \multicolumn{2}{c}{ Body Image } \\
& $\begin{array}{l}\text { Number } \\
\text { Participants }\end{array}$ & of Percentage (\%) \\
Negative & 45 & 14,3 \\
Fairly Positive & 225 & 71,7 \\
Positive & 44 & 14,0
\end{tabular}

an average level of gratitude with a percentage of $74,5 \%$, and 50 respondents with a low level of gratitude with a percentage of $15,9 \%$. According to such results, it can be inferred that the majority of male adolescents in Malang possess an average level of gratitude.

The categorization in table 2 discloses that 44 male adolescents in Malang possess a positive body image of $14 \%$. There are 225 respondents with a fairly positive body image with a percentage of $71,7 \%$ and 45 respondents with a negative body image with a percentage of $15,9 \%$. According to such results, it can be inferred that the majority of male adolescents in Malang possess a fairly positive level of body image.

\subsubsection{Assumption test}

Assumption test shows that data is normally distributed. Based on the calculation of the assumption test using the Kolmogorov-Smirnov, the significance value of the gratitude and body image variables is more than 0.05 . The results of the multicollinearity test state that the data does not experience multicollinearity problems because the tolerance score for the Gratitude $(X)$ variable is $0,557>0,10$ and the VIF score of that variable is $1,796<10$. And the last, heteroscedasticity test, the result is a significance value of 0,517 . As the score surpasses 0,05 , there is no heteroskedasticity. 
TABLE 4: ANOVA simple regression test result.

\begin{tabular}{|c|c|c|c|}
\hline $\mathbf{F}$ & Sig & $\begin{array}{l}\text { Additional } \\
\text { Information }\end{array}$ & Conclusion \\
\hline 92.266 & 0,000 & Sig. $>0,05$ & $\begin{array}{l}\text { There is a role of gratitude to } \\
\text { body image }\end{array}$ \\
\hline
\end{tabular}

TABLE 5: Coefficient table.

\begin{tabular}{l|l|l|} 
Constant & Coefficient & $\begin{array}{l}\text { Simple Linear Regression } \\
\text { Equation }\end{array}$ \\
\hline 39.356 & 0.509 & $\mathrm{Y}=\mathrm{a}+\mathrm{bX} \mathrm{Y}=39.356+0.509 \mathrm{X}$
\end{tabular}

\subsubsection{Hypothesis testing}

The data analysis technique employed in this study is simple linear regression analysis. This technique allows discovering the influence that independent variables have on the dependent ones. The result of the simple linear regression analysis is shown in table 7.

The analysis above discloses the discovered $\mathrm{F}$ score of 92.266 and its significance of 0,000 . As it amounts $\leq 0,05$, it can be inferred that the contribution is significant, which means that the Gratitude variable (X) exerts a significant effect on the Body Image variable (Y).

Table 8 elaborates that the coefficient of simple linear regression aims at a positive direction, which means that the higher the gratitude one has, the better the body image is.

According to the analysis above, the correlation coefficient $R$ is 0,478 with an $R$ square of 0,229 . That score may interpret that the Gratitude $(X)$ plays a part in the $22,9 \%$ variance of Body Image $(Y)$, while the rest $(77,1 \%)$ roots from other factors.

\subsection{Discussion}

The study result shows that gratitude affects body image. This is in line with earlier research by Widawati et al. [14] and Dwinanda [13] who claimed that gratitude and body image are correlated. The more an individual accepts himself, the more he tends to possess a positive body image. Conversely, the more individuals are not grateful for everything that is in themselves, then the individual tends to have a negative body image. Adolescents in the period of development experience physical changes.

TABLE 6: Model summary Table.

\begin{tabular}{l|l}
$\mathbf{R}$ & $\mathbf{R}$ Square \\
\hline 0.478 & 0.229
\end{tabular}


These changes may exert influence on their perspectives and evaluations toward their bodies, feelings, and mind. A study by Nabalis [24] revealed that physical changes in adolescents cause psychological stress. The physical change may also determine how gratitude develops in adolescents. Gratitude is a positive feeling of being thankful in accepting kindness, advantages, or help from other people [25].

Adolescents with a high level of gratitude are majorly in the age range of 20-21 years old and considered as young adults, while adolescents with a low level of gratitude are commonly teenagers in the range of 16-18 years old. The level of gratitude possessed by male adolescents is average. The moderate category of this gratitude variable can describe male adolescent who have quite good acceptance of what is inside of them. It can be interpreted that male adolescents in Malang City are quite capable of controlling their emotions and accepting and appreciating themselves. The gratitude level of an individual is built on some factors, such as self-acceptance, knowledge, experience, social support, spiritual being, appreciation, virtue, positivity, intense spiritual experience, calmness, and optimism in life [26] . As stated by McCullough (in Prabowo [12]), factors in gratitude are namely emotionality, prosociality, and religiousness. Emotionality refers to one's emotional condition in valuing life satisfaction. Prosociality refers to one's social acceptance, while religiousness relates to religious values. The low level of gratitude among adolescents originates from self-acceptance and life satisfaction.

Adolescents with a high level of gratitude possess favorable psychological wellbeing, on the other hand, adolescents with low gratitude will have an effect on low psychological well being [27]. Aside from that, the thankfulness level also correlates with the adolescents' happiness [28]. Adolescents who have high gratitude will feel happy, and vice versa, low gratitude will make it difficult for adolescent to be happy. A study by Widawati et al. [14] later also asserted that the higher the gratitude is, the more positive the body image will be. The lower the gratitude is, the more negative the body image becomes. One's low level of gratitude related to body image issues is frequently provoked by the content in social media and social comparison. According to a study by Tiggemann \& Anderberg [29], there is an effect on men's body satisfaction caused by the exposure to pictures of ideal men on Instagram. An earlier study by Wahyuni \& Wilani ([30] also illustrated how social comparison relates to body image issues. The interpretation of the research results is that individuals with high social comparisons will have a positive body image, and vice versa, individuals with low social comparisons will have a negative body image. In conclusion, gratitude correlates well with the body image variable. 
The finding of this study claims that adolescents with a positive body image largely belong to young adults with an age range of 20-21 years old. Moreover, adolescents with a negative body image are mainly teenagers with the age range of 17-18 years old. The body image possessed by the male adolescents in this study is fairly positive. This demonstrates how male adolescents are capable of accepting their physical appearances, feeling satisfied with their physical conditions, and appreciating their bodies. Every individual may experience a negative tendency to body image, especially adolescents. In line with a study by Denich \& Ifdil [6], the majority of adolescents' body image also pitches toward negative behaviors, such as excessive unhealthy diets, and many more. This is caused by the growth that adolescents experience, specifically the physical changes. In this stage, adolescents are predominantly attracted to physical appearances [31]. Aside from the physical aspect, there is also the emotional aspect that also plays a significant role in adolescents' growth, making these two aspects related to each other. In general, adolescents pay attention to the details of their appearances as they want to appear as attractive as possible. However, physical attraction can also cause adolescents to compare their appearances with others. This provokes body dissatisfaction and a negative body image.

Adolescents with a negative body image generally have low gratitude. This makes teenagers often feel uncomfortable with their physical condition. Adolescents with a negative body image usually lack gratitude, which causes them to feel uncomfortable with their bodies. Adolescents with a negative body image also often worry about their physical flaws and feel dissatisfied with their bodies, which hinders their interpersonal skills and positive social relations with others [2]. As elaborated in the previous sub-chapter, male adolescents with a lack of gratitude tend to judge their physical appearances negatively, causing dissatisfaction against their physical features.

Based on the explanation above, the author has proven the research hypothesis, namely that there is a role for gratitude towards body image. Gratitude gives a big enough influence on body image. Therefore, it is expected that every teenage boy is able to develop gratitude well in himself so that they can minimize the negative body image. This is because a negative body image has several negative impacts on adolescents. The impacts of negative body image include low self-adjustment, difficulty adapting, increasing overweight/obesity factors, and affecting the quality of life of adolescents [32], [33], [34], [35]. This study has limitations including the majority of the sample is male adolescents who occupy the developmental stages of middle and late adolescence, while for early adolescents the number is smaller. 


\section{References}

[1] Santrock JW. Life span development. 13th ed. Boston: McGraw Hill; 2011

[2] Ramanda R, Akbar Z, Wirasti RAMK. Studi kepustakaan mengenai landasan teori body image bagi perkembangan remaja. Jurnal Edukasi: Jurnal Bimbingan Konseling. 2019;5(2):121-135. https://doi.org/10.22373/je.v5i2.5019

[3] Putro KZ. Memahami ciri dan tugas perkembangan masa remaja. Aplikasia: Jurnal Aplikasi IImu-IImu Agama. 2017;17(1):25-32.

[4] Monks F, Knoers AM, Haditono S. Psikologi perkembangan: Pengantar dalam berbagai bagiannya. Yogyakarta:Gajah Mada University Press; 2006.

[5] Grimm J, Schwartz J. Body image and race on gay maletargeted blogs. Howard Journal of Communications. 2017; 28(4):1-16. https://doi.org/10.1080/10646175.2017.1300967

[6] Denich AU, Ifdil. Konsep body image remaja putri. Jurnal Konseling Dan Pendidikan. 2015;3(2):55-61.

[7] Alidia F. Body image siswa ditinjau dari gender. Tarbawi: Jurnal Ilmu Pendidikan. 2018;14(2):7992. https://doi.org/10.32939/tarbawi.v14i2.291

[8] Coen J. De, Verbeken S, Goossens L. Media influence components as predictors of children's body image and eating problems: A longitudinal study of boys and girls during middle childhood. Body Image. 2021;37:204-213. https://doi.org/10.1016/j.bodyim.2021.03.001

[9] Barron AM, Krumrei-Mancuso EJ, Harriger JA. The effects of fitspiration and selfcompassion Instagram posts on body image and self-compassion in men and women. Body Image. 2021;37:14-27. https://doi.org/10.1016/j.bodyim.2021.01.003

[10] Nurvita V, Handayani MM. Hubungan antara self-esteem dengan body image pada remaja awal yang mengalami obesitas. Jurnal Psikologi Klinis Dan Kesehatan Mental. 2015;4(1):1-9.

[11] Layous K, Sweeny K, Armenta C, Na S, Choi I, Lyubomirsky S. The proximal experience of gratitude. PLOS ONE. 2017;12(7):1-26. https://doi.org/https://doi.org/10.1371/journal.pone.0179123

[12] Prabowo A. Gratitude dan psychological well-being pada remaja. Jurnal IImiah Psikologi Terapan. 2017;5(2):260-270.

[13] Dwinanda RF. Hubungan gratitude dengan citra tubuh pada remaja. Jurnal IImiah Psikologi. 2016;9(1):34-41.

[14] Widawati L, Saputra AK, Fauziah DN, Susanti MA. Hubungan rasa syukur dengan citra tubuh pada siswi SMA X Kota Bandung. Psikologia ( Jurnal Psikologi). 2018;3(1):41-50. 
[15] Connell BHO, Shea DO, Gallagher S. Examining psychosocial pathways underlying gratitude interventions: A randomized controlled trial. Journal of Happiness Studies. 2018;19(8):24212444. https://doi.org/10.1007/s10902-017-9931-5

[16] Jans-beken L, Jacobs N, Janssens $M$ et al. Gratitude and health: An updated review. The Journal of Positive Psychology. 2019;15(6):1-41. https://doi.org/10.1080/17439760.2019.1651888

[17] Robustelli BL, Whisman MA. (2018). Gratitude and life satisfaction in the United States and Japan. Journal of Happiness Studies. 2018;19(1):41-55. https://doi.org/10.1007/s10902-016-9802-5

[18] Watkins PC, Woodward K, Stone T, Kolts RL. Gratitude and happiness: Development of a measure of gratitude, and relationships with subjective well-being. Social Behavior and Personality. 2003;31(5):431-452. https://doi.org/10.2224/sbp.2003.31.5.431

[19] Soulliard ZA, Kauffman AA, Fitterman-Harris HF, Perry JE, Ross MJ. Examining positive body image, sport confidence, flow state, and subjective performance among student athletes and non-athletes. Body Image. 2019;28:93-100. https://doi.org/10.1016/j.bodyim.2018.12.009

[20] Ahadzadeh AS, Rafik-Galea S, Alavi M, Amini M. Relationship between body mass index, body image, and fear of negative evaluation: Moderating role of self-esteem. Health Psychology Open. 2018;10(5):1-8. https://doi.org/10.1177/2055102918774251

[21] Turel T, Jameson M, Gitimu P, Rowlands Z, Mincher J, Pohle-krauza R. Disordered eating: Influence of body image, sociocultural attitudes, appearance anxiety and depression - A focus on college males and a gender comparison. Cogent Psychology. 2018;5(1):1-22. https://doi.org/10.1080/23311908.2018.1483062

[22] Cash TF, Pruzinsky T. Body images: A handbook of theory, research, and clinical practice. New York:Guildford Press; 2002.

[23] Sugiyono, S. Metode Penelitian Kuantitatif, Kualitatif dan R\&D. Bandung:Alfabeta; 2016.

[24] Nabalis Al. Stress psikologis pada remaja. Journal of Holistic and Traditional Medicine (JHTM). 2016;1(2):402-406.

[25] Teguh PM, Prasetyo E. Dinamika gratitude pada ibu yang memiliki anak Down Syndrome. Jurnal Experentia. 2021;9(1):1-9.

[26] Hambali A, Meiza A, Fahmi I. Faktor-Faktor yang berperan dalam kebersyukuran (gratitude) pada orangtua anak berkebutuhan khusus perspektif psikologi Islam. Psympathic: Jurnal IImiah Psikologi. 2015;2(1):94-101. 
[27] Pridayanti T, Indrawati E. Hubungan antara forgiveness dan gratitude dengan psychological well being pada remaja di panti asuhan $x$ bekasi. Jurnal IKRA-ITH Humaniora. 2019;3(3):197-206.

[28] Lubis B. Syukir dengan kebahagiaan remaja. Jurnal Pionir LPPM Universitas Asahan. 2019;5(4):282-287.

[29] Tiggemann M, Anderberg I. Muscles and bare chests on Instagram: The effect of Influencers' fashion and fitspiration images on men's body image. Body Image. 2020;35:237-244. https://doi.org/10.1016/j.bodyim.2020.10.001

[30] Wahyuni GAKTE, Wilani NMA. Hubungan antara komparasi sosial dengan citra tubuh pada remaja laki-laki di Denpasar. Jurnal Psikologi Udayana. 2019;6(1):945-954.

[31] Aristantya EK, Helmi AF. Citra tubuh pada remaja pengguna instagram. Gadjah Mada Journal of Psychology (GamaJoP). 2019;5(2):114. https://doi.org/10.22146/gamajop.50624

[32] Demirdel S, Ülger Ö. Body image disturbance, psychosocial adjustment and quality of life in adolescents with amputation. Disability and Health Journal. 2021;14(3):1-6. https://doi.org/10.1016/j.dhjo.2021.101068

[33] Ganeswari AAIG, Wilani NMA. Hubungan antara citra tubuh dengan kecenderungan body dysmorphic disorder (BDD) pada remaja akhir laki-laki di Denpasar. Jurnal Psikologi Udayana. 2019;6(1):65-75. https://doi.org/10.24843/jpu.2019.v06.i01.p07

[34] Mini Y, Sudargo T, Tsani AFA, Huriyati E. Citra tubuh dan perilaku makan sebagai faktor risiko overweight remaja putra di SMA negeri kota palu. Jurnal Dunia Gizi. 2019;2(2):101-107.

[35] Musba E, Abidin Z. Hubungan antara body image dengan penyesuaian diri pada remaja pria yang melakukan latihan fitness. Empati: Jurnal Karya IImiah S1 Undip. 2014;3(2):147-156. 